\title{
Pertumbuhan Curah Enterococcus faecalis Id 6017 dan Kemampuan Dekolorisasi Reactive Red-2 pada Medium yang Mengandung Gliserol
}

\section{Bacth Culture of Enterococcus faecalis Id 6017 and Its Ability to Decolorize Reactive Red-2 in the Glycerol Containing Medium}

\author{
V. I. Meitiniarti*, Morina M. Napitupulu, K. H. Timotius \\ Fakultas Biologi, Universitas Kristen Satya Wacana, \\ Jl. Diponegoro 52-60 Salatiga Telp. 0298-321212, ex. 305 Fax. 0298-321433 \\ E-mail:rien@uksw.edu *Penulisuntuk korespondensi
}

\begin{abstract}
Enterococcus faecalis ID 6017 can utilize glycerol as the source of carbon and energy for its growth. The present of glycerol in the medium containing Reactive Red-2 not only influenced its growth but also its ability to decolorize Reactive Red-2. The aim of this study was to investigate the growth of Enterococcus faecalis (E. faecalis) and its ability to decolorize Reactive Red-2. The microbe was grown in batch system with three different growth medium, i.e. medium which contained (i) $1.643 \mathrm{~g} / \mathrm{l}$ glycerol and $0.08 \mathrm{~g} / \mathrm{l}$ reactive red-2, (ii) $1.643 \mathrm{~g} / \mathrm{l}$ glycerol, and (iii) $0.08 \mathrm{~g} / \mathrm{l}$ Reactive Red 2 . The result of this study showed that the growth of $E$. faecalis and its ability to decolorize Reactive Red-2 on medium contained glycerol was better than without glycerol. $E$. faecalis could not growth and decolorized Reactive Red-2 on medium without glycerol.
\end{abstract}

Key words : E. faecalis, glycerol, Reactive Red- 2, decolorize

Diterima: 3 Febuari 2003, disetujui: 10 September 2003

\section{Pendahuluan}

Industri tekstil umumnya menggunakan berbagai pewarna sintetik sebagai pewarna kain. Salah satunya adalah Reactive Red-2 yang termasuk golongan monoazo dan memiliki ikatan kromofor pada naftalena. Proses pewarnaan kain, seperti pencelupan dan pembilasan, menghasilkan limbah cair yang mengandung pewarna dan bahan organik dan diperkirakan $10-15 \%$ pewarna terlepas dalam efluen selama proses pewarnaan tersebut (Vaidya and Datye, 1982, dalam Spadaro et al., 1992).

Pewarna azo tidak dapat didegradasi pada kondisi aerob sehingga pada proses pengolahan air limbah aerob konvensional, biasanya tidak terjadi dekolorisasi yang efisien (Zimmermen et al. 1982) dan senyawa ini masih dijumpai pada efluen unit pengolahan aerob (Schultze-Rellmer, 1996 dalan Keck et al. 1997). Walaupun pada beberap proses pengolahan limbah secara biolog tradisional yang dikombinasi dengan perlakua fisika dan kimiawi, seperti flokulasi, koagulas kimiawi, dan presipitasi, dapat menghasilka dekolorisasi efluen yang lebih baik. Perlakua tersebut ternyata masih menimbulkan masalal karena menghasilkan lumpur yang banyak Selain itu polusi akibat penggunaan baha kimia yang berlebihan juga perlu ditangan secara terpisah. Oleh karena itu, perl dikembangkan suatu metode alternatif untu dekolorisasi menggunakan metode biolog inovatif alami dan dapat mengurangi poluta (Chang et al., 2001). Pengolahan secar biologis tersut dapat dilakukan dengan bantua suatu mikroorganisme.

Penelitian sebelumnya berhasi mengisolasi bakteri dengan sandi SWCL 
96-I03 (Liem, 1997) dari lumpur aktif industri tekstil. Bakteri tersebut telah dilaporkan mampu mendekolorisasi berbagai macam pewarna, seperti amaranth (Oei dan Meitiniarti, 1999; Meitiniarti dan Rahayu, 2002), merah reaktif (Mangimbulude et al., 2002), kuning dan biru reaktif (Meitiniarti dan Alexandra, 2001). Lebih lanjut diketahui bahwa kultur bakteri tersebut terdiri dari dua jenis bakteri, yaitu Enterococcus faecalis ID6017 dan Chryseobacterium indologenes ID6017 (Meitiniarti dan Timotius, 2002). Kemampuan dekolorisasi pewarna kedua jenis bakteri tersebut belum banyak diteliti. Menurut Robert et al. (1996), E. faecalis termasuk golongan bakteri asam laktat, anaerob fakultatif yang habitatnya berada pada saluran pencernaan manusia dan hewan (Schaberg et al., 1991, dalam Rince et al., 2001), mampu tumbuh pada medium yang mengandung gliserol, manitol, pada $\mathrm{pH} 6,5$ - 9,2, dan suhu optimum pertumbuhannya adalah $37^{\circ} \mathrm{C}$. Pada beberapa penelitian dilaporkan bahwa bakteri saluran pencernaan manusia dan hewan mampu mendegradasi senyawa pewarna (Rafii et al., 1990; Brown, 1981; McConnel and Tannock, 1991). Jadi besar kemungkinan E. faecalis ID6017 dalam kultur murni juga mempunyai kemampuan dekolorisasi pewarna.

Menurut Nigam et al. (1996) dalam Tan and Field (2000), terjadinya reduksi pewarna azo dibutuhkan ketersediaan ko-substrat. Kosubstrat yang digunakan dapat berupa glukosa, pati, tapioka, ekstrak khamir, atau campuran asetat, butirat dan propionat. Gliserol dapat digunakan oleh E. faecalis sebagai sumber karbon dan energi. Ada kemungkinan gliserol dapat digunakan sebagai kosubtrat untuk pertumbuhan pada medium yang mengandung Reactive Red-2, karena Reactive Red-2 merupakan senyawa xenobiotik yang tidak dapat digunakan langsung sebagai sumber $\mathrm{C}$ dan energi. Dengan demikian, tujuan penelitian ini adalah mengetahui pertumbuhan dan kemampuan E. faecalis dalam dekolorisasi Reactive Red-2 pada medium yang mengandung gliserol dalam sistem curah.

\section{Bahan dan Metode Penelitian}

\section{Bahan yang digunakan}

Biak E. faecalis ID6017 diperoleh dari laboratorium Mikrobiologi, Fakultas Biologi, Universitas Kristen Satya Wacana. Salatiga. Medium pertumbuhan yang digunakan mempunyai komposisi dasar sebagai berikut (g/L): $\mathrm{MgSO}_{4} .7 \mathrm{H}_{2} \mathrm{O} \quad 0,25 ; \quad\left(\mathrm{NH}_{4}\right)_{2} \mathrm{SO}_{4} \quad 1,98$; $\mathrm{K}_{2} \mathrm{HPO}_{4} \quad 5,55 ; \quad \mathrm{KH}_{2} \mathrm{PO}_{4} \quad 2,13$; dan ekstrak khamir 0,5. Gliserol 1,643 g/l dan Reactive Red- 2 0,08 g/l.

\section{Kondisi pertumbuhan}

Pertumbuhan E. faecalis dilakukan dalam sistem curah pada kondisi statis. E. faecalis ditumbuhkan pada tiga macam medium pertumbuhan yaitu medium yang mengandung gliserol dan Reactive Red-2, medium yang mengandung gliserol saja, dan medium yang mengandung Reactive Red-2 saja.

Sebelum dilakukan pertumbuhan ,terlebih dahulu dibuat prekultur. Prekultur dibuat dengan cara menginokulasikan E.faecalis yang berumur 24 - 48 jam ke dalam $50 \mathrm{ml}$ medium pertumbuhan sesuai perlakuan. Kemudian diinkubasi selama 24 - 48 jam. Saat serapan optis pada $\lambda=540 \mathrm{~nm}$ mencapai kisaran 0,3-0,5 prekultur dimasukkan ke dalam medium pertumbuhan. Selama pertumbuhan dilakukan pengambilan sampel setiap selang waktu tertentu. Parameter yang diukur adalah konsentrasi Reactive Red-2 (secara kolorimetri pada $\lambda 480 \mathrm{~nm}$ ), konsentrasi gliserol (secara kolorimetri pada $\lambda 570 \mathrm{~nm}$, Dawes, et al., 1971) dan konsentrasi sel.

\section{Hasil dan Pembahasan}

Pertumbuhan E. faecalis ID 6017

E. faecalis ID6017 dapat tumbuh pada medium yang mengandung gliserol baik dengan atau tanpa Reactive Red-2 karena gliserol digunakan sebagai sumber karbon. Adanya gliserol pada medium pertumbuhan akan mempengaruhi pertumbuhan E. faecalis dan kemampuannya dalam dekolorisasi 
Reactive Red-2. Pada medium yang mengandung Reactive Red-2 tanpa gliserol (Gambar 3), E. faecalis tidak dapat tumbuh karena tidak dapat menggunakan Reactive Red2 secara langsung sebagai sumber karbon maupun energi bagi pertumbuhannya. Jika $E$. faecalis ditumbuhkan pada medium yang mengandung Reactive Red 2 dan substrat yang dapat digunakan secara langsung, maka bakteri ini akan tumbuh dan dekolorisasi Reactive Red-2 (Gambar 2). Tetapi keberadaan Reactive Red-2 dalam medium akan memperlambat pertumbuhan bakteri. Kecepatan pertumbuhan E. faecalis pada medium dengan gliserol dan
Reactive Red-2 lebih lambat, peroleha biomassanya lebih sedikit, dan konsums gliserolnya lebih banyak (Gambar 2 dan Tabe 1) dibandingkan pada medium dengan glisero saja (Gambar 1). Hal ini disebabkan pad medium dengan gliserol dan Reactive Red-2, faecalis menggunakan gliserol tidak hany untuk tumbuh melainkan juga untu. memutuskan ikatan kromofor Reactive Red-2 Sedangkan pada medium dengan gliserol saja gliserol hanya digunakan untuk tumbuh da memelihara atau mempertahankan sel.

Tabel 1. Perhitungan Parameter Pertumbuhan dan Dekolorisasi Reactive Red-2 oleh E-faecalis ID6017

\begin{tabular}{lcc}
\hline \multirow{2}{*}{ Parameter Pertumbuhan } & \multicolumn{2}{c}{ Medium Gliserol } \\
\cline { 2 - 3 } & Dengan Reactive Red-2 & Tanpa Reactive Red-2 \\
\hline Kecepatan Pertumbuhan Spesifik $(\mu)\left(\mathrm{Jam}^{-1}\right)$ & 0,08 & 0,18 \\
Produksi sel $(\mathrm{mg} / \mathrm{l})$ & 78 & 189 \\
Konsumsi gliserol $(\mathrm{mg})$ & 560,3 & 412,8 \\
Konsumsi Reactive Red-2 $(\mathrm{mg})$ & 62,12 \\
Persentase dekolorisasi $(\%)$ & 93 & \\
\hline
\end{tabular}

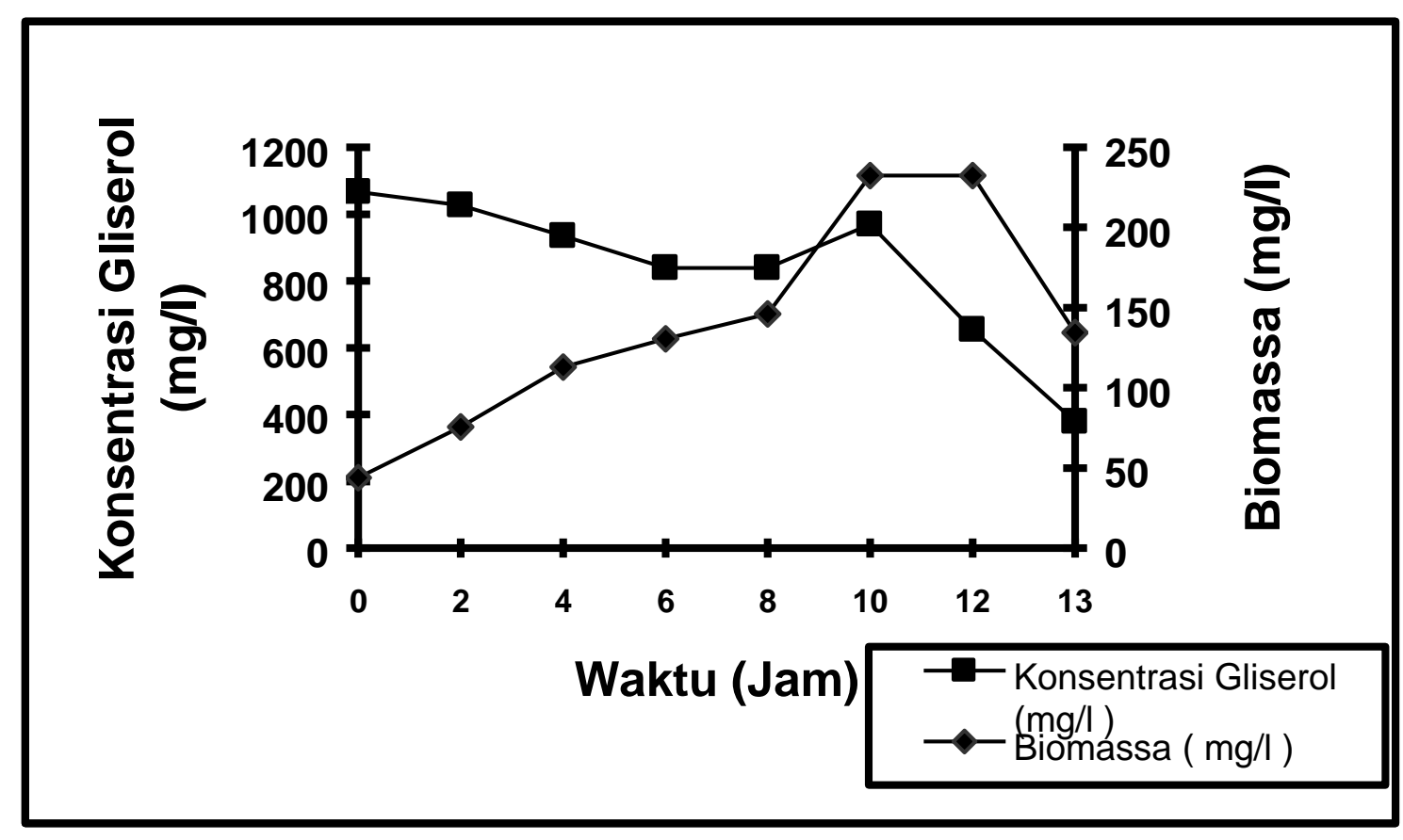






Gambar 2. Pertumbuhan E. faecalis ID-6017 pada medium yang mengandung gliserol dan Reactive Red- 2

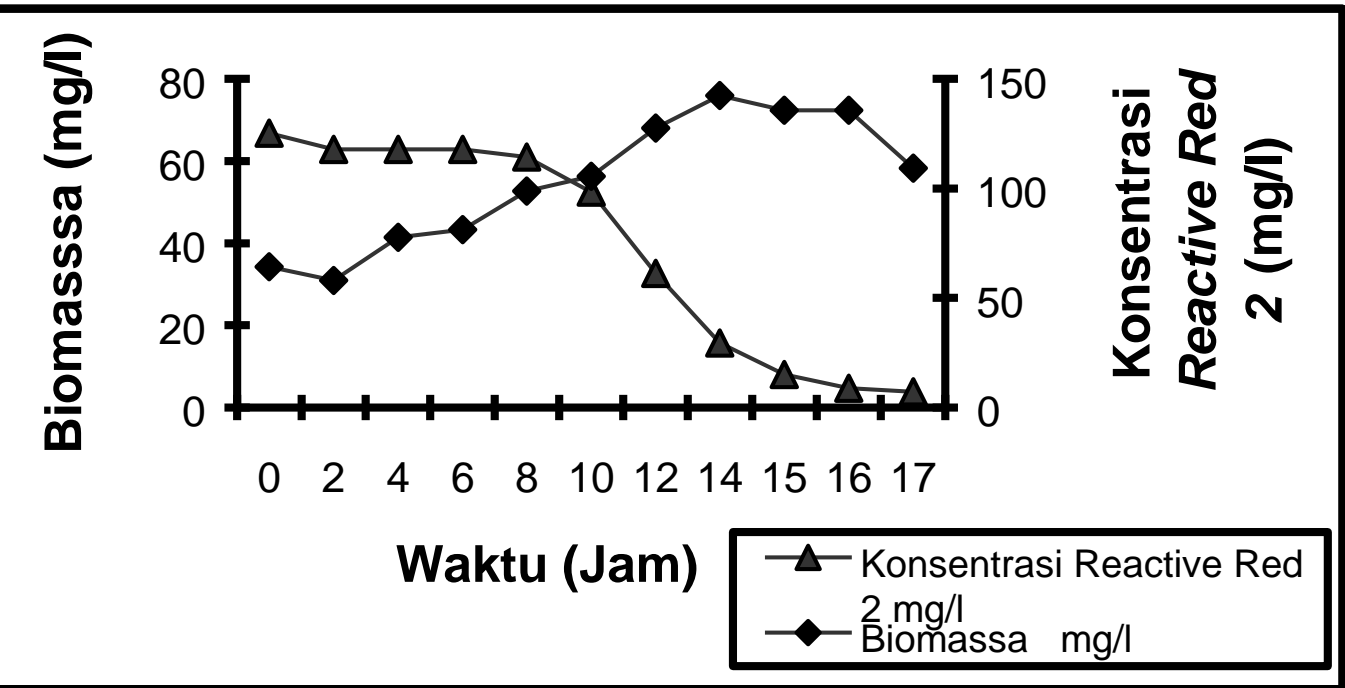

Gambar 3. Penurunan konsentrasi Reactive Red-2 selama pertumbuhan E. faecalis ID6017 dalam medium tanpa gliserol



Gambar 4. Penurunan konsentrasi gliserol dan Reactive Red-2 oleh E. faecalis ID6017 
Dekolorisasi Reactive Red -2 oleh E. faecalis ID 6017

Tingkat penurunan konsentrasi Reactive Red-2 terjadi seiring dengan peningkatan tingkat konsumsi gliserol dan konsentrasi sel (Gambar 3 dan 4). Dekolorisasi Reactive Red-2 terjadi apabila sel dalam keadaan tumbuh. Peran gliserol dalam proses dekolorisasi adalah sebagai sumber donor elektron. Dari gliserol akan dihasilkan NADH yang berfungsi memacu aktivitas azoreduktase untuk memutuskan ikatan kromofor pada Reactive Red-2 sehingga konsentrasi Reactive Red-2 berangsur-angsur menurun (terdekolorisasi). Senyawa hasil dekolorisasi Reactive Red-2 diduga adalah aromatik amin (Haug et al., 1991).

\section{Kesimpulan}

Pertumbuhan E. faecalis ID 6017 pada medium yang mengandung gliserol lebih baik dibnadingkan medium non-gliserol. Penambahan Reactive Red-2 pada medium yang mengandung gliserol dapat menghambat pertumbuhan E. faecalis ID 6017.

Keberadaan gliserol pada medium yang mengandung Reactive Red-2, diperlukan untuk pertumbuhan E. faecalis ID 6017 dan proses dekolorisasi. Jika tidak ada gliserol, maka bakteri tidak tumbuh.

\section{Daftar Pustaka}

Brown, J.P. 1981. Reduction of Polymeric Azo and Nitro Dyes by Intestinal Bacteria. Applied and Environmental Microbiology 41 (5): 1283-1286.

Chang, J.S, Chou, C., Lin, Y.C., Lin, P.J. et al., 2001. Kinetic Characteristics of Bacterial Azo Dyes Decolorization By Pseudomonas luteola. Water Research 35 (12): 2841-2850

Dawes, E. A., D.J. Mc Gill and M. Midgley. 1971. Analysis of Fermentation Product. In: J.R. Norris and D.W. Ribbons (Eds.) Methods in Microbiology. Academic Press. New York.
Haug, W., A. Schmidt., B. Nortemann. et al., 1991 Mineralization of the Sulfonated Azo Dye Mordant Yellow 3 by a 6-Aminonaph thalene-2-Sulfonate-Degrading Bacteria Consortium. Applied and Environmento Microbiology 57 ( 11 ) : 3144-3149.

Keck, A., J. Klein, M. Kudlich, A. Stolz, H-J. et al 1997. Reduction ofazo dyes by redo mediators originating in th naphthalenesulfonic acid degradatio pathway of Sphingomonas sp. strain BNe Applied and Environmental Microbiology 6 (9): 3684-3690.

Liem, D.L. 1997. Identifikasi dan Karakterisas Isolat-isolat Bakteri Pereduksi Amarant yang Diisolasi dari Limbah Industri Teksti Skripsi S1 Fak. Biologi, UKSW. Salatiga.

Mangimbulude, J.C., V.I. Meitiniarti, dan Haryanti. 2002. Efek Beberapa Kosubstra terhadap Degradasi Merah Reaktif ole Brevibacterium sp. SWCU-96-I03 dalar Kondisi Aerob. Makalah dalam Semina Nasional FMIPA, UNNES, Semarang, 2. April 2002.

McConnel, M.A. and G.W. Tannock. 1991 Lactobacilli and Azoreductase Activity i the Murine Cecum. Applied an Environmental Microbiology 57 (12): 3664 3665 .

Meitiniarti, V.I. dan S. Alexandra. 2001 Kemampuan Dekolorisasi Pewarna Kuning Merah, dan Biru Reaktif oleh Isolat SWCU 96-I03 pada Kondisi Anaerob. Ser Penelitian FB Vol. 4, No. 1 September 2001

Meitiniarti, V.I. dan Y.G.S.P. Rahayu. 2002 Pengaruh Glukose dan Ekstrak Khami terhadap Pertumbuhan dan Kemampua Dekolorisasi Amaranth oleh Brevibacteriur sp. SWCU-96-I03. Seri Penelitian FB Vol. 5 No. 1 Maret 2002.

Meitiniarti, V.I. dan K.H. Timotius. 2002 Karakterisasi dan Identifikasi bakteri SWCl 96-I03 dan SWCU 96-I01 sert Pertumbuhan dan Kemampua Dekolorisasinya pada Medium yan Mengandung Pewarna. Laporan Penelitia Fak. Biologi, UKSW. Salatiga. 
Oei, I. dan V.I. Meitiniarti. 1999. Pengaruh Penambahan Glukosa dan Pengocokan Medium terhadap Pertumbuhan Brevibacterium sp. SWCU-96-I03 dan Kemam-puannya dalam Menurunkan Warna Amaranth. Seri Penelitian FB No. 2 Th. II Maret 1999.

Rafii, F., W. Franklin, and C.E. Cerniglia. 1990. Azoreductase Activity of Anaerobic Bacteria Isolated from Human Intestinal Microflora. Applied and Environmental Microbiology 56 (7): 2146-2151.

Rince, A., J-C. Giard, V. Pichereau, S. Flahaut, et $a l, 2001$. Identification and Characterization of gsp65, an Organic Hydroperoxide Resistance (ohr) Gene Encoding a General Stress Protein in Enterococcus faecalis. Journal of Bacteriology 183 (4): 1482-1488.

Robert, T.A., A.C.B. Parker, and R.B. Tompkin. 1996. Microorganisms in Foods. Microbiological Spesification of Food Pathogen. $5^{\text {th }}$ ed. Blakie Academic and Profesional. London.
Spadaro, J.T., M.H. Gold, and V. Renganathan. 1992. Degradation of azo dyes by lignindegradating fungus Phanerochaete chrysosporium. Applied and Environmental Microbiology 58 (8): 2397-2401.

Tan, N.C.G. and J.A. Field. 2000. Biodegradation of Sulfonated Aromatic Compound. In: Lens, P. and L. Hulshoff-Pol (Eds.) Environmental Technologies to Treat Sulfur Pollution. Principles and Engineering. IWA Publishing. London.

Zimmermen, T., H.G. Kulla, and T. Leisinger. 1982. Properties of purified Orange II azoreductase, the enzyme initiating azo dye degradation by Pseudomonas KF46. Europe Journal of Biochemistry 129: 197-203. 